\title{
Practices and Challenges of Continuous Assessment in Colleges OF TEACHERS EDUCATION IN WEST OROMIA REGION OF ETHIOPIA
}

\author{
Gemachu Oli ${ }^{1)}$, Teklu Tafase Olkaba ${ }^{2)}$ \\ 1) College of Education and Behavioral Science, Jimma University, Ethiopia \\ E-mail: gemechuoli@gmail.com \\ 2) College of Education and Behavioral Science, Jimma University, Ethiopia \\ E-mail:teklu252@yahoo.com
}

\begin{abstract}
The main purpose of this study was to investigate the practices and challenges of continuous assessment in colleges of teachers' education in western Oromia region. For this study, the researchers selected three colleges of teachers education purposely based on the job experience. The researchers selected Nekemte, Dembi Dollo and Shambo colleges teachers education from well, medium, lower experienced respectively. A descriptive survey design involving both qualitative and quantitative approaches was employed. 134 student-teachers and 178 college teachers were selected and participated in the study. The quantitative data was collected through a questionnaire and observation checklist and analyzed using frequency and percentage, whereas, the qualitative data interview and document analysis were analyzed using the narrative form and interpretative way. The finding of the study revealed that the extent of practicing continuous assessment in class is low. The study also showed that teachers have positive perceptions toward continuous assessment and they accepted continuous assessment as important to improve the achievement of learners. The finding disclosed that large class size, shortage of time, teachers workload, the low interest of students, large instructional content, and lack of commitment among teachers as the major factors hindering the practice of continuous assessment in colleges of teachers education. The researchers recommend that educational authorities and stockholders should make effort to students per class to manageable numbers, College administrators should allow teachers to cover the minimum workload than overloading above the standard set for the college of teachers education.
\end{abstract}

Keywords: Continuous Assessment; College Students; College Teachers’ Education; Evaluation; Standardized Testing

\section{INTRODUCTION}

Since the endorsement of the 1994 Ethiopian education and training policy, different teacher training models have been introduced to improve the quantity and quality of teachers that, in turn, bring the quality of education as a whole. The impetus of teaching and teaching profession is to bring up and shaping generations in the world of profession impacting nation development. In line with this argument Ethiopian education and training policy of 1994 article 3.4 with the sub-articles $4.3 .1 ; 3.4 .3 \& 3.4 .5$ and article 3.6 subarticle 3.6.2 states about teacher and teacher education, respectively, as:

1. Ascertain that teacher trainees have the ability, diligence, professional interest, and physical and mental fitness appropriate for the profession.
2. Teacher education and training components will emphasize basic knowledge and professional code of ethics,

3. A professional career structure will be developed in respect to professional development of teachers.

4. The participation of teachers and researchers in getting the necessary field experience in various development and service institutions and professionals of such institutions in teaching will be facilitated (TGE, ETP, 1994: 23-28).

According to the education and training policy of Ethiopia (Transitional Government of Ethiopia, TGE, 1994), the efforts designed to make teachers and teaching profession at the highest ladder tip was well articulated in the policy document. According to the teacher training policy document, continuous assessment is the pillar of the teacher training policy to translate the notion of active learning methods into practice that realizes the potential of the students and on the quality of education at all levels. To 
achieve effective education in one country continuous assessment is important. Assessment is one of the elements of the instructional process that plays an important role to improve learning in educational institutions.

As stated in Educational and Training Police (MoE, 1994), the practical task of implementing the new curriculum at the school level requires a continuous assessment as part of the curriculum in general and the instructional process in particular. To understand this, the role of teachers is of paramount importance. In other words, teachers should be well informed about the concept and procedures of practicing continuous assessment before they implement it. In relation to this, (Teshome, 2001; USAID/BEP, 2006) suggested that teachers' knowledge and attitude should be considered for the effective practice of the assessment program. The educational progress of learners needs frequent assessment. The various aspects of the learning activities of learners should be assessed by various methods. The traditional assessment method mainly focuses on testing which encourages superficial learning but did not assess the wider skills of pupils. Thus, continuous assessment should be essential to measure learners' performance in a holistic manner. As the researchers are college teachers they observed from their experience that there were problems related to using varieties of continuous assessment techniques in college.

Continuous assessment is a typical classroom-based strategy that provides regular information about the teaching-learning process. Concerning this, Ellington and Earl (1997) suggested that continuous assessment is practiced on a day to day basis to judge the quality of the individual's work or performance. Employing continuous assessment enables the teacher to assess more of the intended behavior of the students and to take note of factors such as their active participation, how articulate they are, their relationships with others and their motivation that have high educational relevance (Livingston, 2001). Continuous assessment is a student evaluation system that operates at a classroom level and is integrated with the instructional process.

So far, many researchers conducted different studies on the problem in different ways. For instance, Getinet (2016) conducted a study on the assessment of the implementation of continuous assessment and found that the majority of the teachers on continuous assessment practices were not well understood, the objectives behind the importance of continuous assessment were not clear to most teachers. Yet few who were aware did not practice, and fieldwork and project were not commonly applied. These are other reasons that initiated the researchers initiated to undertake the study. Therefore, the main aim of this study was to investigate the practices and challenges of continuous assessment in colleges of teachers' education in western Oromia region, Ethiopia. The specific objectives of the study were

1. To identify the perception of teachers toward continuous assessment in Colleges of Teachers' Education in the West Oromia region.

2. To find out the extent of teachers' practice continuous assessment in Colleges of Teachers' Education in West Oromia region.

3. To identify the major factors that influence the practice of continuous assessment in Colleges of Teachers' Education in the West Oromia region.

\section{LITERATURE REVIEW}

\section{A. The Conceptual Framework of the Study}

Many scholars wrote about the definition of assessment in different ways. Regarding this, Greaney and Kelladhan (2001) state that the term assessment "may be used in education to refer to any procedure or activity that is designed to collect information about the knowledge, attitudes, or skills of a learner or a group of the learner". They also stated that "assessment is the process of obtaining information that is used to make the educational decisions about students, to give feedback to the students about his or her progress, strengths and weakness or to judge instructional effectiveness and circular adequacy and to inform policy". Again according to Brown (2004) an assessment is an act of interpreting information about students' performance collected through any of multitude of means or practices. It the procedure through which information about pupils is obtained by any method or procedure that is formally or informally.

Assessment is broader than testing and measurement because it includes all kinds of ways to sample and observe students' skills (psychomotor domain), knowledge (cognitive domain), values and emotions (affective domain). People often equate assessment with tests, measurement and evaluation (Ugodulunwa, 1996). Assessment, however, is quite different in concept. According to Airasian (1994) measurement involves the assigning of members to represent the amount something possessed by an objective event or system. Students are doing in terms of specific objectives. Tests are used for summative evaluation. Tests embedded in the curriculum materials provided they match the specified learning outcomes. Tests the teacher creates, they are aligned with the learning outcomes. Teachers can use tests to help students using assessment procedures as teaching tools. Often, the test can be used to control students' behavior and communicating achievement expectations to the student (Madaus \& Kellagan, 1993).

\section{Assessment Paradigms}

The growing current kinds of literature identify four assessment paradigms to classroom assessment that can be used in conjunction with each other: assessment for learning, assessment as learning, assessment of learning and assessment in learning (Mercy, 2012).

Assessment for Learning: is an ongoing, diagnostic and school-based process that uses a variety of assessment tools to assess learner performances (Kapambwe, 2010). It reflects a view of learning in which assessment helps students learn better, rather than just achieve a better mark, involves formal and informal assessment activities as part of learning and to inform the planning of future learning, includes clear goals 
for the learning activity, provides effective feedback that motivates the learner and can lead to improvement, reflects a belief that all students can improve, encourages selfassessment and peer-assessment as part of the regular classroom routines, involves teachers, students and parents reflecting on evidence and inclusive of all learners.

Assessment as Learning: occurs when students are their own assessors. Students monitor their own learning, ask questions and use a range of strategies to decide what they know and can do, and how to use assessment information for new learning. Assessment as learning: encourages students to take responsibility for their own learning, requires students to ask questions about their learning, involves teachers and students creating learning goals to encourage growth and development, provides ways for students to use formal and informal feedback and self-assessment to help them understand the next steps in learning and encourage peer assessment, self-assessment and reflection.

Assessment of Learning: assists teachers in using evidence of student learning to assess achievement against outcomes and standards. In this assessment paradigm, teacher directedness is paramount and the student has little involvement. Sometimes referred to as 'summative assessment', it usually occurs at defined key points during a teaching work or at the end of a unit, term or semester, and may be used to rank or grade students. The effectiveness of assessment of learning for grading or ranking purposes depends on the validity, reliability and weighting placed on any one task. This implies that it is teachers' design learning and collecting evidence to decide what has been learned and what has not particularly at the end of instruction.

Assessment in learning: it places questions at the center of teaching and learning. It deflects teaching from its focus on a 'correct answer' to focus on a' fertile question.' Through inquiry, students engage in processes that generate feedback on their learning, which comes from multiple sources and activities (Takele, 2010). It contributes to the construction of other learning activities, lines of inquiry and generations of other questions. Students are at the center of learning, monitor, assess, and reflect on learning and initiate demonstration of learning (to self and others).

Besides, the teacher plays a role as a coach and mentor in this model. Moreover, teachers and students need to understand the purpose of each assessment strategy, so that the overall assessment 'package' being used by learners and teachers accurately captures and uses meaningful learning information to generate deep learning and understanding.

\section{Assessment Methods}

The Portfolio Assessment: it must be more than just a collection of student work to give a full picture of what the learner has achieved (Puhl, 1997). It has also stated that portfolio-based assessment is an important means of individualized, student-centered evaluation. Portfolio assessment has the potential to improve the complex task of student assessment (Reece \& Walker, 2003). More specifically, portfolios are essentially different from other forms of assessment in that they make it possible to document the unfolding process of teaching and learning over time. In relation to this, Apple and Shino (2004) stated portfolios as a collaborative assessment, partly determined by the classroom teacher and partly by the learner. As Nitko (1996) pointed out, portfolio assessment is a new trend to make authentic assessments pertaining to students' performance or products in classrooms.

Self-assessment: Given the chance, students can assess themselves quite accurately stated by Muluken (2006). Supporting this idea, Puhl (1997) suggested that selfappraisal exercises are likely to increase the motivation of learners. Thus, self-assessment has a strong impact on active learning to the extent of realization that students have the ultimate responsibility for their own learning. It can help students to pinpoint their strengths and weaknesses and find ways of improvement (Haris, 1997).

Peer Assessment: Students are encouraged to assess each other's learning and understanding, taking responsibility for supporting their classmates and making progress together. In light of this, Puhl (1997) put the idea of peer assessment as a response in some form to other learners' work. It can be given by a group or an individual and it can take any of a variety of assessment techniques.

Projects: can be given individually or in groups that encourage students to become active and independent learners. Whether projects are used early or late in the course, the time that is needed must is time Tabled for students as well as for teachers (Brown et al., 1997). They further stated that projects encourage students to work together and reflect on their work. Furthermore, Spandel and Stiggins (1990) asserted that projects are important to show the attitude, skills, knowledge and the learning process of students as they engage in activities.

Interviews and Conferences: Teacher-student interviews or conferences are productive means of assessing individual achievement and needs. Spandel and Stiggins (1990) stated that during discussions, teachers can discover students' perceptions of their own processes and products of learning. According to Martin (1997), interviewing is one of the best ways to find out how much children have learned and how well they understand what they have learned. Conferences can be used more widely as part of the assessment and may take the form of a discussion between teachers and students about schoolwork (Gensee \& Upshure, 1996). As Gensee, and Upshure (1996); and Martin (1997) pointed out, interviews and conferences are the truly authentic ways of obtaining information about learners' achievement and their thinking. To attain this, open-ended and partially structured questions can be used.

Quizzes, Tests, and Examinations are parts of the traditional mode of assessment. They are most often used for assessing students' knowledge of content; nevertheless, they may be used for assessing processes skills and attitudes, (Struyven et al., 2002). According to Hayes (1997) quizzes, tests and examinations are used as assessment mechanisms in combination with alternative methods of assessment these days. This shows paper and pencil tests and alternative 
methods of assessment complement each other. This enables the teacher to have detailed, valid and reliable information about the students and the teaching-learning process. Most often, quizzes and tests are part of the continuous assessment and examinations are part of the summative assessment.

Continuous Assessment: is a more formative means of assessing learners that gives an opportunity for them to improve their performance. It is used as a process of gathering and integrating information about learners shifting from a judgmental role to a developmental role (Puhl, 1997). Continuous Assessment is carried out at periodic intervals for the purpose of improving the overall performances of learners and of the teaching/learning process (Obioma, 2005).

Airasian (1994) defined continuous assessment as a mechanism that shows the full range of sources and makes teachers use to gather, interpret and synthesize information about learners. Continuous assessment of learners' progress could be defined as a mechanism whereby the final grading of learners in the cognitive, affective and psychomotor domains of learning systematically takes account of all their performances during a given period of schooling.

Another definition (Airasian, 1994; Tesfaye, 2005) describe continuous assessment as an assessment approach which should depict the full range of sources and methods teachers use to gather, interpret and synthesize information about learners; information that is used to help teachers understand their learners, plan and monitor instruction and establish a viable classroom culture. From these definitions, one could infer that continuous assessment is an assessment approach that involves the use of a variety of assessment instruments, assessing various components of learning, not only the thinking processes but including behaviors, personality traits and manual dexterity. Continuous assessment will also take place over a period of time. Such an approach would be more holistic, representing the learner in his/her entirety. It will begin with the decisions that the teachers perform on the first day of school and end with the decisions that the teachers and administrators make on the learners regarding end-of-year grading and promotion.

\section{METHODOLOGY}

The design of this study was a descriptive survey involving both qualitative and quantitative method data gathering methods. This method is preferred as it helps the researchers to investigate the current practices and challenges about the issue under study. Further, the use of applying qualitative and quantitative methods simultaneously is to complement the weakness of one method by the other method.

\section{A. Sample Size and Sampling Techniques}

TABLE I

Total Population, SAMPle Size, AND SAMPling TeChNiQuE

\begin{tabular}{clllll}
\hline S/N & Sample CTE & Population Name & Population & Sample & Sampling Technique \\
\hline 1 & Dambi Dollo CTE & Regular student-teachers & 1605 & 482 & Systematic random \\
& & Teachers & 61 & 61 & Census \\
& & Dean and vice dean & 2 & 2 & Census \\
\hline 2 & \multirow{2}{*}{ Shambo CTE } & Regular student-teachers & 1026 & 308 & Systematic random \\
& & Teachers & 43 & 43 & Census \\
& & Dean and vice dean & 2 & 2 & Census \\
\hline 3 & Nekemte CTE & Regular student-teachers & 2000 & 601 & Systematic random \\
& & Teachers & 74 & 74 & Census \\
& & Dean and vice dean & 2 & 2 & Census \\
\hline Total & & $\mathbf{4 8 1 5}$ & $\mathbf{1 5 7 5}$ & \\
\hline
\end{tabular}

Key: CTE represents college teachers' education

\section{B. Data Collection Instruments}

For this study, different data collection instruments: questionnaire, interview, classroom observation and document review were employed.

Questionnaire: Many scholars wrote about the importance of the questionnaire to collect information from respondents. Creswell (2012: 382) states that "questionnaire is a form used in survey design that participants in a study complete and return to the researchers." It is a means of eliciting beliefs and practices of individuals on the issue under study. In this study, the questionnaire was the main instrument to collect data from teachers and student-teachers.

Interviews: Semi-structured face-to-face interviews were used which allows for further probing of respondents' answers (Hayes, 1997). Semi-structured face-to-face interviews may provide the researchers with flexibility and to explore more deeply about the practices and challenges on continuous assessment and the perception of teacher educators towards continuous assessment at the colleges. Therefore, to get the additional information and strengthen the data obtained via questionnaires, the researchers prepared a semi-structured interview of 5 items. The interview was held with deans and vice deans from each college regarding the perception teachers, practices and challenges of continuous assessment at the colleges.

Classroom observation: Observation is a purposeful, systematic and selective way of watching and listening to an interaction or phenomenon as it takes place. There are many situations in which observation is the most appropriate strategy of data collection. Observation helps researchers to get real behavior rather than elicit reports of preference or 
intended behavior in the form of self- report data (Yin, 2011; Creswell, 2012). The researchers used this tool to see how teachers practice continuous assessment in practice in their classrooms. This enables the researchers to triangulate the response of the study participant with the real practices of continuous assessment.

\section{Data Analysis}

The document analysis started from the inception of the review on Ethiopian education and training policies and practices. The primary focus was on recent documents updated or originating on the Ethiopian teacher training system focusing on continuous assessment and the present practices and the significant changes or shifts in the teacher training reform. The initial document analysis provided a base understanding of the factors driving changes in continuous assessment. All the collected data using questionnaires and observation checklist were organized and categorized to quantify numerically. Data generated from document review, interview and questionnaire were schematized while data generated from FGDs were narrated. Finally, the data from the three colleges of teachers education were, triangulated against the policy documents to draw lessons. Final researchers' experiences led to draw the conclusion of the study and policy implications for future actions.

\section{RESULTS AND DISCUSSION}

\section{A. Presentation of the Findings}

As illustrated in Table II, concerning the sex of teachers participants, about 170 (95.5\%) of them were males, whilst $8(4.6 \%)$ were female teachers who participated in the study. As the data of teachers shows that, there was a low proportion of female teachers in colleges of teachers' education which contradicts Ethiopian Education Sector Development Program V (ESDP-V 2016-2020). Furthermore, Table II portrayed that teachers' service year were as follows: $61(34.3 \%)$ of teachers were between the service year range of $16-20$ and $40(22.5 \%)$ of them were between the experience range of 21-25 years. As well as, the remaining participants, 40(22.5\%), 14(7.9\%), 12(6.7\%) and $1(0.6 \%)$ of teachers participants were between the range of
$15-15,6-10,>25$ and 1-5 years of experiences respectively. This implies that the majority of the participants have rich experiences of teaching and learning activity.

Regarding teachers load per week, the majority of 153 $(86 \%)$ of the teacher had less than 15 periods and $13(7.3 \%)$ of participants had between 15-20 periods and the rest of the participants have between $21-25$ periods and above 25 periods per week respectively. This indicates the majority of college teachers have no overload period per week in their regular classes. Concerning the educational background of teachers, $28(15.73 \%)$ teachers are first degree holders and $139(78.08 \%)$ of teachers are Master's Degree holders. The rest only $11(6.17 \%)$ of them were diploma holders. This clearly shows that the most teachers in the colleges are Master's Degree holders with respect to the educational status and requirement to undertake their activities relevant to the job offered at this level.

Furthermore, as shown in Table III, the student/class size reveals that majority $162(91 \%)$ of the teacher participants opined that about 40-59 students follow their education in a class while the rest $14(7.9 \%)$ and $2(1.1 \%)$ of them opined as about 60-79 and 30-39 students learn in a class respectively.

As Table IV shows, the proportion of student-teachers sex was almost a balance since $706(50.7 \%)$ and 685(49.7) were males and females respectively. As Table IV indicated, the age group of the student-teachers participants, about $395(28.3 \%)$, and $228(16 \%)$ were range between $21-25$ and $16-20$ respectively. This shows that the majority of studentteachers participants were between 21-25 years. Therefore, the age statistics imply that the college student-teachers are dominated by the younger level.

As indicated in Table V, Item 1 , about $8(4.5 \%)$ and 15 $(8.4 \%)$ of teachers were responded daily and every two or three with the frequently practicing of continuous assessment in their instruction. On the other hand, about 67 $(33.7 \%)$ and $60(15.7 \%)$ of teacher participants responded once in a semester and twice in a semester with the frequently practicing continuous assessment in their instructions. Besides this questionnaire the response the interviewed college vice dean was given as follows:

TABLE II

CHARACTERISTICS OF RESPONDENTS OF the TEACHERS By THEIR SEX, Age, AND Service YeAR

\begin{tabular}{|c|c|c|c|c|c|c|c|c|c|c|c|c|c|c|c|c|}
\hline \multirow[b]{2}{*}{ Participants } & \multicolumn{9}{|c|}{ Age } & \multicolumn{6}{|c|}{ Service year } & \multirow[b]{2}{*}{ Total } \\
\hline & Sex & & 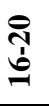 & 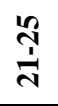 & ஜֶ. & 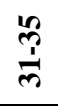 & 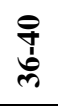 & $\underset{7}{\stackrel{1}{7}}$ & $\begin{array}{l}0 \\
\dot{0} \\
\dot{1}\end{array}$ & $\underset{n}{\frac{5}{\sigma}}$ & $\stackrel{\Xi}{\Xi}$ & $\begin{array}{l}\overrightarrow{7} \\
Z_{1} \\
\text { in }\end{array}$ & $\begin{array}{l}\text { ஸे } \\
\text { in }\end{array}$ & 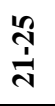 & $\stackrel{n}{\wedge}$ & \\
\hline \multirow{4}{*}{ Teachers } & \multirow{2}{*}{ Male } & $F$ & - & - & 6 & 15 & 74 & 57 & 18 & - & 12 & 37 & 61 & 48 & 12 & 170 \\
\hline & & $\%$ & - & - & 3.4 & 8.4 & 42 & 32 & 10 & - & 6.7 & 21 & 34 & 27 & 67 & 95.5 \\
\hline & \multirow{2}{*}{ Female } & $F$ & & 1 & 2 & 1 & 3 & 1 & - & 1 & 2 & 3 & - & 2 & - & 8 \\
\hline & & $\%$ & - & 0.6 & 1.1 & 0.6 & 1.7 & 0.6 & - & 0.6 & 1.1 & 1.7 & - & - & 0.6 & 4.6 \\
\hline Total & & & - & 1 & 8 & 16 & 77 & 58 & 18 & 1 & 14 & 40 & 61 & 50 & 12 & 178 \\
\hline
\end{tabular}

Key: F= Frequency, \%=Percentage 
TABLE III

TEACHERS Work LoAd, EdUCATION LEVEL, AND Class SizE

\begin{tabular}{llcc}
\hline Item & & $\boldsymbol{F}$ & $\mathbf{\%}$ \\
\hline Teachers load per week & less than 15 per week & 153 & 86 \\
& $15-20$ per week & 13 & 7.3 \\
& $21-25$ per week & 6 & 3.4 \\
& more than 25 per week & 6 & 3.4 \\
\cline { 2 - 4 } & Total & $\mathbf{1 7 8}$ & $\mathbf{1 0 0}$ \\
\hline Educational qualification & Diploma & 11 & 6.17 \\
& First Degree & 28 & 15.7 \\
& Master's degree & 139 & 78.1 \\
\cline { 2 - 4 } & Total & $\mathbf{1 7 8}$ & 1.1 \\
\hline Class size (class-student ratio) & $30-39$ students & 2 & 91 \\
& $40-59$ students & 162 & 7.9 \\
\hline
\end{tabular}

Key: F= Frequency, \%=Percentage

TABLE IV

CHARACTERISTICS OF RESPONDENTS OF THE STUDENTS By THEIR SEX, AND AGE

\begin{tabular}{|c|c|c|c|c|c|c|c|}
\hline \multirow[b]{2}{*}{ Participants } & \multicolumn{6}{|c|}{ Age } & \multirow[b]{2}{*}{ Total } \\
\hline & Sex & & ণิ & 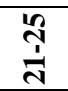 & లి & $\frac{n}{n}$ & \\
\hline \multirow{4}{*}{ Students } & & $F$ & 228 & 395 & 62 & 21 & 706 \\
\hline & Male & $\%$ & 16 & 28.3 & 4.5 & 1.5 & 50.7 \\
\hline & & $F$ & 291 & 384 & - & 10 & 685 \\
\hline & Female & $\%$ & 21 & 28 & - & 0.7 & 49.7 \\
\hline \multicolumn{3}{|c|}{ Total } & 519 & 779 & 62 & 31 & 1391 \\
\hline
\end{tabular}

Key: $\mathrm{F}=$ Frequency, $\%=$ Percentage

TABLE V

TEACHERs PRACTICE OF CONTINUOUS ASSESSMENT IN TEACHING LEARNING ACTIVITIES

\begin{tabular}{|c|c|c|c|c|c|c|c|c|c|c|c|c|}
\hline \multirow{2}{*}{ Items } & \multicolumn{2}{|c|}{5} & \multicolumn{2}{|c|}{4} & \multicolumn{2}{|c|}{3} & \multicolumn{2}{|c|}{2} & \multicolumn{2}{|c|}{1} & \multicolumn{2}{|c|}{ Total } \\
\hline & $F$ & $\%$ & $F$ & $\%$ & $F$ & $\%$ & $F$ & $\%$ & $F$ & $\%$ & $F$ & $\%$ \\
\hline $\begin{array}{l}\text { Frequently practicing of } \\
\text { continuous assessment }\end{array}$ & 8 & 4.5 & 15 & 8.4 & 28 & 15.7 & 60 & 33.7 & 67 & 37.6 & 178 & 100 \\
\hline $\begin{array}{l}\text { How frequent do you use } \\
\text { classwork in the actual teaching } \\
\text { process }\end{array}$ & 9 & 5.1 & 21 & 11.8 & 65 & 36.5 & 31 & 17.4 & 52 & 29.2 & 178 & 100 \\
\hline $\begin{array}{l}\text { How frequently do you use oral } \\
\text { question in your class }\end{array}$ & 59 & 33.1 & 67 & 37.6 & 33 & 18.5 & 10 & 5.6 & 9 & 5.1 & 178 & 100 \\
\hline $\begin{array}{l}\text { How often do you use class } \\
\text { activity in your class }\end{array}$ & 11 & 6.2 & 22 & 12.4 & 41 & 23 & 53 & 29.8 & 51 & 28.7 & 178 & 100 \\
\hline $\begin{array}{l}\text { How frequent do you give } \\
\text { assignment to your students }\end{array}$ & 50 & 28 & 58 & 32.6 & 48 & 27 & 22 & 12.4 & 0 & 0 & 178 & 100 \\
\hline How often do you use tests & 53 & 29.6 & 62 & 34.8 & 35 & 19.7 & 13 & 7.3 & 15 & 8.4 & 178 & 100 \\
\hline How frequent do you use exams & 51 & 28.7 & 59 & 33.1 & 43 & 24.2 & 25 & 14 & 0 & 0 & 178 & 100 \\
\hline
\end{tabular}

Key: $5_{=}$Daily, $4=$ every $2 / 3$ days, $3=$ every week, $2=$ Twice in a semester, $1=$ Once in a semester, $F=F r e q u e n c y, \%=P e r c e n t a g e$

"In our college, there is the beginning of the practice of continuous assessment but it is not this much satisfactory because there are students who have no interest when they are assessed by continuous assessment. Especially, our college students did not like to do assignments and home works. The commitment of our college teachers is also low and there is an overlook between our teachers. Due to this, I can generalize that currently as our college the technique was not effectively practiced and it needs more effort and works." (Vice dean W, Date, 02/03/2019)

One of the vice dean in college also strength the response of above as follows:

"In our college, the practice of continuous assessment is more or less on a good condition and many of our college teachers practice it. But when I say in good condition I do not mean that there is no limitation on practice it. Because, there is degree of variation between our college teachers on dedicating to practice the program and there are factors that hinder them to 
fully practice continuous assessment. The actual practices of continuous assessment by our teachers were; tests, quiz, oral question, individual and group assignment were the most commonly used assessment methods at the end of each unit" (Vice dean E, Date, 08/03/2019).

As indicated in Table V, item 2 above, about $9(5.1 \%)$, $21(11.8 \%)$ and $65(36.5 \%)$ of the participants responded daily, every $2 / 3$ days and every week about the frequency of using classwork activity respectively and about 31 (17.4\%) and $52(29.2 \%)$ of participants responded twice in a semester and once in a semester with frequently using classwork activity in their classes.

As Table V item 3 shows, about 9 (5.1\%), 10 (5.6\%) and $33(18.5 \%)$ of the participants responded once in a semester, twice a semester and every week with frequently using an oral question in their sessions and about 57 (33.1\%) and 67 (37.6\%) of the participants responded daily and every $2 / 3$ days with frequently using an oral question in their sessions to increase student-teachers participation and improve their learning. In the same way in above Table V, item 4 above, about $11(6.2 \%), 22(12.4 \%)$ and $41(23 \%)$ of the participants responded as daily, every $2 / 3$ days and every week with frequent use of class activity in their sessions and about $53(29.8 \%)$ and $51(28.7 \%)$ of the participants responded once in a semester and twice in a semester with frequent use of class activity in their sessions to increase student-teachers participation and improve their learning.

As Table V item 5 shows, about 22 (12.4\%) and 48 (27\%) of teachers responded twice in a semester and every week with frequently giving assignments to their students and the rest about $58(32.6 \%)$ and 50 (28\%) of participants responded as every $2 / 3$ days and daily with frequently giving the assignment to their students in their schools. The Table V item 6 reveals, about 13 (7.3\%), 15 (8.4\%) and $35(19.7 \%)$ of the participants responded twice in a semester, once in a semester and every week with frequently using tests to measure students learning performance respectively and the rest about $62(34.8 \%)$ and $53(29.6 \%)$ of the participants responded every $2 / 3$ days and daily with frequently using tests to measure students learning performance. Similarly to this idea, One of the college dean also strength the response and point out that:

"Our teachers did not encourage student-teachers to participate during teaching and learning and they teach them without giving chance for students and they run fast to cover the portion only and our teacher gave tests and assignment many times, especially this year our teacher was giving at least one tests per three week and one assignment per a month. During this year our teachers used different assessment such as assignment, quizzes, written tests and others instead of using single mid examination." (Vice dean M, Date 05/03/2019)

From these participants, it is possible to deduce that even if college teachers use different assessment techniques there was somewhat limited by the teachers on using different assessment techniques to measure students' achievement. This means since continuous assessment involves the use of great values of modes of evaluation for the purpose of guiding and improving the learning and performance of students, the teachers are required to use different modes effectively for the benefit of the learners.

As indicated in Table $\mathrm{V}$, most of the college teachers use oral questions, assignments, tests, and exams as the most frequently used assessment technique. Therefore, from this one can infer most of the College teachers make use of limited continuous assessment techniques rather than finding alternative methods to reach all the students. Supporting this, Brown, Bull, and Pendlebury (1997) advised that if essays are used as the only form of assessment, students writing may improve, but other skills may remain undeveloped. In the same way, NOE (2004) explained that evaluation of students' acquisition of knowledge and skills is an integral part of the teaching-learning processes and continuous assessment is an assessment approach that involves the use of a variety of assessment instruments to assess various components of learning.

As Table VI describes the response by student-teachers on the extent of continuous assessment practiced by their teachers in-class teaching, accordingly, item 1 describes 239 (17.2\%), 197(14.2)\% and $83(5.9 \%)$ of the participants responded 2-3 day, once in a semester and daily with a frequency of teachers gives classwork, while the rest 498 $(35.8 \%)$ and $374(26.9 \%)$ of student-teachers were responded as every week and twice in a semester with the frequency of teachers in conducting classwork in their colleges. As the Table VI item 2 shows, about 176 (12.7\%) and $73(5.2 \%)$ of participants agree weekly and 2-3 day with teachers frequently giving practical activity for their students and the rest about $685(49.3 \%)$ and $457(32.8 \%)$ of them were responded as once in a semester and twice in a semester respectively with the idea.

As shown in the Table VI item 3, about 249 (17.9\%), 145 $(10.5 \%)$ and $73(5.2 \%)$ of student-teachers participants agree twice a semester, daily and once in a semester with how frequently teachers give homework for students to strengthen their knowledge from their class and the rest $601(43.3 \%)$ and $323(21 \%)$ of student-teachers participants were opined as every week and 2-3 day with how frequently teachers give homework for students. In the same Table VI, item 4 , about $41(3 \%)$ and $93(6.7 \%)$ of students responded once in a semester and every $2 / 3$ days with how frequent teachers ask their students an oral question and the rest 997 $(71.6 \%)$ and $260(18.7 \%)$ of student-teachers responded every week and once in a semester with how frequent teachers ask their students an oral question to see and examine their understanding about the topic of their learning. 
TABLE VI

Student-Teachers Practice of CONTINUOUS ASSESSMENT IN TEACHING LEARNing ACTIVITIES

\begin{tabular}{|c|c|c|c|c|c|c|c|c|c|c|c|c|}
\hline \multirow{2}{*}{ Items } & \multicolumn{2}{|c|}{5} & \multicolumn{2}{|c|}{4} & \multicolumn{2}{|c|}{3} & \multicolumn{2}{|c|}{2} & \multicolumn{2}{|c|}{1} & \multicolumn{2}{|c|}{ Total } \\
\hline & $F$ & $\%$ & $F$ & $\%$ & $F$ & $\%$ & $F$ & $\%$ & $F$ & $\%$ & $F$ & $\%$ \\
\hline $\begin{array}{l}\text { How frequent your teachers give you } \\
\text { class work in your class }\end{array}$ & 83 & 5.9 & 239 & 17.2 & 498 & 35.8 & 374 & 26.9 & 197 & 14.2 & 1391 & 100 \\
\hline $\begin{array}{l}\text { How frequent do your teachers give } \\
\text { you a practical activities }\end{array}$ & - & - & 73 & 5.2 & 176 & 12.7 & 457 & 32.8 & 685 & 49.3 & 1391 & 100 \\
\hline $\begin{array}{l}\text { How frequent do your teachers give } \\
\text { you a home work }\end{array}$ & 145 & 10.5 & 323 & 21 & 601 & 43.3 & 249 & 17.9 & 73 & 5.2 & 1391 & 100 \\
\hline $\begin{array}{l}\text { How frequent do your teachers ask } \\
\text { you oral question in the class }\end{array}$ & - & - & 93 & 6.7 & 997 & 71.6 & 260 & 18.7 & 41 & 3 & 1391 & 100 \\
\hline $\begin{array}{l}\text { How frequent your teacher observe } \\
\text { your work }\end{array}$ & 197 & 14.2 & 280 & 20.1 & 426 & 30.6 & 332 & 23.9 & 156 & 11.2 & 1391 & 100 \\
\hline $\begin{array}{l}\text { How frequent your teacher assess your } \\
\text { performance with project work }\end{array}$ & - & - & 176 & 12.7 & 270 & 19.4 & 426 & 30.6 & 519 & 37.3 & 1391 & 100 \\
\hline
\end{tabular}

Key: 5 = Daily, 4 = every two or three days, 3 = every week, $2=$ Twice in a semester, $1=$ Once in a semester, F= Frequency,

$\%=$ Percentage

As indicated in Table VI item 5, about $280(20.1 \%), 197$ (14.2\%), and 156 (11.2\%) of participants responded 2-3 day, daily and once a semester with how frequent teachers observe the work of their students in the class respectively and the rest $426(30.6 \%)$ and $332(23.9 \%)$ of participants responded every week and twice a semester with how frequent teachers observe the work of their students in the class. On the same Table VI item 6 indicated that about 270 $(19.4 \%)$ and $176(11.9 \%)$ of student-teachers were responded as every week and 2-3 day with how frequently teachers assess student-teachers performance by giving project work and the rest $519(37.3 \%)$ and $426(30.6 \%)$ of student-teachers responded twice a semester and once a semester with how frequently teachers assess studentteachers performance by giving project work.

One of the Vice dean in college $E$ also strength the response of students and said that:

"Our teachers did not encourage students to participate during teaching and learning and they teach without giving chance for students and they run fast to cover the portion only. Again our teachers do not identify the level of students and the measures students by preparing question which we are not learned in the class."(Date 01/04/2014)

As a result of an analysis shows, the majority of studentteachers confirmed that their teachers are not fully practicing the continuous assessment activities. From this one can infer that the majority of teachers use similar assessment techniques.

Regarding continuous assessment, mark list was properly analyzed and important notes were taken from three colleges of Teachers Education in 2011/2018/9 academic year and 36 achievement record sheets were investigated. The mark lists of continuous assessments contain a variety of assessment techniques like individual assignment, group assignment, quiz, test, mid-exam and final exam. According to Table VII, the teacher used only a few places of mark lists to fill students' marks. Table VII depicts that quiz, test, exam and assignments are used as continuous assessment techniques in colleges of teachers' education. Document review was made to validate or identify the consistency of the questionnaire of response with actual teachers practice given for the subject included in the study.

Finally, the researchers observed that most of the assessment formats were not appropriate to record every activity of the learners. Because, space given to assessment format was more convenient to record terminal assessment i.e. are: test, quiz, mid-exam and final exam than different types of assessment. From this one can conclude that the majority of teachers use similar assessment techniques and they have the basic skill of recording and documenting students' continuous assessment achievement. The actual practices of continuous assessment by teachers were; quiz, test, exam, individual and group assignment were the most commonly used assessment methods.

TABLE VII

ISSUES ANALYZED IN STUDENT MARK LIST FORMAT

\begin{tabular}{|c|c|c|c|}
\hline \multirow{2}{*}{ Issues Analyzed } & \multicolumn{2}{|c|}{ Responses } & \multirow{2}{*}{ Remarks } \\
\hline & Yes & No & \\
\hline Is there observation in mark list format as a tool & & $\times$ & None exist \\
\hline Is there presentation in mark list format as a tool & & $x$ & None exist \\
\hline Is there assignment in mark list format as a tool & $\sqrt{ }$ & & Exist \\
\hline Is there project work in mark list format as a tool & & $x$ & None exist \\
\hline Is there laboratory work in mark list format as a tool & & $x$ & None exist \\
\hline Is there test in mark list format as a tool & $\sqrt{ }$ & & Exist \\
\hline Is there quizzes in mark list format as a tool & $\sqrt{ }$ & & Exist \\
\hline Is there exam in mark list format as a tool & $\sqrt{ }$ & & Exist \\
\hline
\end{tabular}


TABLE VIII

TEACHER's PERCEPTION TOWARDS PROBLEMS OF CONTINUOUS ASSESSMENT PRACTICES

\begin{tabular}{|c|c|c|c|c|c|c|c|c|c|c|c|c|}
\hline \multirow{2}{*}{ Items } & \multicolumn{2}{|c|}{ SA } & \multicolumn{2}{|c|}{$\mathbf{A}$} & \multicolumn{2}{|c|}{ UD } & \multicolumn{2}{|c|}{ D } & \multicolumn{2}{|c|}{ SD } & \multicolumn{2}{|c|}{ Total } \\
\hline & $F$ & $\%$ & $\boldsymbol{F}$ & $\%$ & $F$ & $\%$ & $\boldsymbol{F}$ & $\%$ & $F$ & $\%$ & $\boldsymbol{F}$ & $\%$ \\
\hline Class size & 63 & 35.4 & 55 & 30.9 & 16 & 9 & 34 & 19 & 10 & 5.6 & 178 & 100 \\
\hline Teachers negative attitude on CA & 15 & 8.4 & 6 & 3.4 & 19 & 10.7 & 83 & 46.6 & 55 & 30.9 & 178 & 100 \\
\hline Shortage of time & 22 & 12.4 & 109 & 61.2 & 31 & 17.4 & 4 & 2.2 & 12 & 6.7 & 178 & 100 \\
\hline Lack of awareness/knowledge & 2 & 1.1 & 13 & 7.3 & 81 & 45.5 & 49 & 27.5 & 13 & 7.3 & 178 & 100 \\
\hline Shortage of teaching materials & 11 & 6.2 & 31 & 17.4 & 51 & 28.7 & 71 & 39.9 & 14 & 7.9 & 178 & 100 \\
\hline Teachers workload & 51 & 28.7 & 77 & 43.3 & 17 & 9.6 & 2 & 1.1 & 31 & 17.4 & 178 & 100 \\
\hline Low interest of students & 48 & 27 & 52 & 29.2 & 27 & 15.17 & 25 & 14 & 26 & 14.6 & 178 & 100 \\
\hline Large instructional content & 33 & 18.5 & 74 & 41.6 & 53 & 29.8 & 6 & 3.4 & 12 & 6.7 & 178 & 100 \\
\hline $\begin{array}{l}\text { Lack of commitment among } \\
\text { teachers }\end{array}$ & 42 & 23.5 & 48 & 26.9 & 34 & 19.1 & 30 & 16.8 & 24 & 13.5 & 178 & 100 \\
\hline
\end{tabular}

Key: SA= strongly agree, $\mathrm{A}=$ Agree, $\mathrm{UD}=$ Undecided, $\mathrm{D}=$ Disagree, $\mathrm{SD}=$ strongly disagree, $\mathrm{f}=$ Frequency, $\%=$ Percentage

The data in Table VIII depicts major factors influencing the practice of continuous assessment in colleges of teachers' education.

Class size: to express deliberately how large class size affects the practice of continuous assessment, about $63(35.4 \%)$ and $55(30.9 \%)$ of the teachers opined as strongly agree and agree with class size problem. Related to this idea, One of the college vice dean said as follow:

"It is very difficult to manage more than 50 students in a single class and come up with an effective practice of continuous assessment. Had there been less number of students, it would have been manageable for continuous assessment to be fully practiced." (Dean E, Date, 08/03/2019)

In connection with this idea, Hayes (1997) contended that the problem of large class size is very serious to assess student's classwork and homework. Similarly, Ellington and Earl (1997) and Papworth (2005) indicated that large class size is the most limiting problem that affects the implementation of continuous assessment.

Shortage of time: Table VIII indicates that about $109(61.2 \%)$ and $22(12.4 \%)$ of participants opined as agree and strongly agree on a time constraint as continuous assessment practice. Regarding this, one of the interviewed vice dean points out:

"Teachers are offering many different courses per semester. Furthermore, they are expected to complete the course from which they are assigned to offer according to the schedule given to them by the office of the registrar. In additional to this they are doing practicum part I up to IV and they are correct practicum portfolio and take reflection. This makes them busy" (Vice dean W, Date, 02/03/2019).

The interest of students: As could be observed from above, the majority of participants had the perception that time was one of the constraints above Table VIII item 8 indicated about $48(26.96 \%)$ and $52(29.21 \%)$ of teacher respondents were opined as strongly agree and agree with low interest of students as a problem affecting the practice of continuous assessment. College Dean had the following to say regarding the low interest of students:

"Most student-teachers are not familiar with the newly developed continuous assessment program. They were accustomed to taking mid, final and national entrance exams when they were at secondary school. Hence, here at college level, when teachers tell them that they had finished their evaluation out of sixty percent in the classroom, they complain their dissatisfaction and even sometimes they were seen to be shocked by the information from the teacher" (Dean M, Date, 05/03/2019).

The majority of respondents accepted that low readiness of students influenced teachers not to fully practice continuous assessment as effectively as possible.

Teachers workload: Table VIII item 6 indicated, about $17(9.6 \%)$ of them also responded as undecided about teachers workload as a problem affecting continuous assessment practice in their colleges respectively and about $77(43.3 \%)$ and $51(28.7 \%)$ of the teachers confirmed that agree and strongly agree with teachers workload as a problem affecting the practice of continuous assessment in their classes. In line with this, one of the interviewed college dean points out:
"Our teachers are offering many different courses per semester. Most of our college teachers teach more than four courses, especially, Education stream and language stream have load of different courses. In addition to this teachers are doing practicum, involving in different committees, teaching night and weekend program. Therefore, they run in shortage of time to practice continuous assessment successfully. As a result, it is easy to imagine how challenging them each course through continuous assessments" (Dean W, Date, 15/03/2019).

Large instructional content: Table VIII item 8 indicated about $33(18.5 \%)$ and $74(41.6 \%)$ of teacher participants were opined as strongly agree and agree with large instructional content as a problem affecting the practice of continuous assessment. Regarding this, one of the interviewed vice dean points out:

"The credit hour given and subject content is mismatched in many courses and teachers are not covering the portion of lesson on time. For this reason teachers are run for cover of portion rather than practice continuous assessment" (Vice dean M, Date, 04/03/2019).

In line with these facts, the most commonly mentioned challenge to implement continuous assessment is insufficient time allocation for the course. 
Lack of commitment among teachers: According to Table VIII, about 48(29.96\%) and 42(23.59\%) of participants very claims as agree and strongly agree with lack of commitment among teachers as a problem affecting continuous assessment practice in their learning activities.

In line with this, One of the college vice dean said as follow:

"Currently the criteria for promotion, transfer and training are not clear for many of teachers. Someone can be given a better position because of friend ship or long years of teaching experience while there are teachers who have shown a high level of efficiency and performance in teaching. This makes them less committed" (V W, Date, 02/03/2019).

It can be concluded that class size, shortage of time, the interest of students, teachers workload, large instructional content and lack of commitment are among teachers are the major factors that influence the practice of continuous assessment in the college of teachers' education.

As revealed in Table IX, the majority of participants $345(24.6 \%)$ and $570(41 \%)$ participants responded agree and strongly agree with class size problem. Table IX item 3 indicated, about $249(17.9 \%)$ and $654(47 \%)$ of studentteachers responded agree and strongly agree that time constraint is one of the problem impacts of the practice continuous assessment. In the same manner, about 353 $(25.4 \%)$ and $405(29.1 \%)$ of student-teachers responded agree and strongly agree with teachers' workload as a problem affecting the practice of continuous assessment in their classes.

Accordingly, most of the student-teachers confirmed that Class/student size, shortage of time, and a heavy workload were identified as a major problem affecting the practice of continuous assessment in their colleges. Accordingly, most of the student-teachers confirmed that Class/student size, shortage of time, and a heavy workload were identified as a major problem affecting the practice of continuous assessment in their colleges.

College vice dean had the following to say regarding the challenges of continuous assessment:

"The teachers have the necessary skills of recording and documenting students' continuous assessment achievements. But the main problem is a large numbers of students in the class, Shortage of time, high loads of many courses and low interests of students are an obstacle to practice continuous assessment properly" (Vice dean E, Date, 08/03/2019).

Generally, According to the data processed the most serious factors affecting the practicing continuous assessment are: class size, Shortage of time, Low readiness of students, Teachers workload, Large instructional content and Lack of commitment among teachers were the major factors that influence the practice of continuous assessment in their learning activities.

TABLE IX

Student-Teacher's Perception on Continuous Assessment Practices

\begin{tabular}{|c|c|c|c|c|c|c|c|c|c|c|c|c|}
\hline \multirow{2}{*}{ Items } & \multicolumn{2}{|c|}{5} & \multicolumn{2}{|c|}{4} & \multicolumn{2}{|c|}{3} & \multicolumn{2}{|c|}{2} & \multicolumn{2}{|c|}{1} & \multicolumn{2}{|c|}{ Total } \\
\hline & $\boldsymbol{F}$ & $\%$ & $\boldsymbol{F}$ & $\%$ & $\boldsymbol{F}$ & $\%$ & $\boldsymbol{F}$ & $\%$ & $\boldsymbol{F}$ & $\%$ & $F$ & $\%$ \\
\hline Class size & 343 & 24.6 & 570 & 41 & 125 & 9.0 & 322 & 23.1 & 31 & 2.2 & 1391 & 100 \\
\hline Teachers attitude on CA & 52 & 3.7 & 187 & 13.4 & 882 & 63.4 & 218 & 15.7 & 52 & 3.7 & 1391 & 100 \\
\hline Shortage of time & 654 & 47 & 249 & 17.9 & 114 & 8.2 & 218 & 15.7 & 156 & 11.2 & 1391 & 100 \\
\hline Knowledge problem & 145 & 10.4 & 21 & 1.5 & 207 & 14.9 & 436 & 31.3 & 581 & 41.8 & 1391 & 100 \\
\hline Education aid problem & 197 & 14.2 & 93 & 6.7 & 561 & 40.3 & 343 & 24.6 & 197 & 14.2 & 1391 & 100 \\
\hline $\begin{array}{l}\text { Problem of teachers insufficient } \\
\text { preparation }\end{array}$ & 342 & 24.6 & 125 & 9 & 52 & 3.7 & 478 & 34.3 & 394 & 28.4 & 1391 & 100 \\
\hline Heavy work load of teachers & 353 & 25.4 & 405 & 29.1 & 197 & 14.2 & 208 & 14.9 & 228 & 16.4 & 1391 & 100 \\
\hline Lack of support from college for & 322 & 23.1 & 218 & 15.7 & 561 & 40.3 & 145 & 10.4 & 145 & 10.4 & 1391 & 100 \\
\hline
\end{tabular}

teachers

Key: 5= strongly agree, 4 = Agree, $3=$ Undecided, 2 = Disagree, $1=$ strongly disagree, $F=$ Frequency, \%=Percentage.

\section{B. Discussion}

\section{Teachers' Perception towards Continuous Assessment}

The finding revealed that teachers have positive perceptions and understanding of continuous assessment. The finding from this study is similar to that of Temesgen (2017) finding on the teachers' perception and practices towards continuous assessment that states teachers' have positive perceptions and understanding about continuous assessment. In relation to this, Teshome (2001) suggested that teachers' knowledge and attitude should be considered for effective implementation of the assessment program. According to the response obtained from questionnaires of teachers and interviews of deans and vice deans, most the teachers have positive perceptions and understanding about continuous assessment. A new continuous assessment program can succeed only if teachers accept it. If teachers do not accept the philosophy of this program, it is clear that it is not possible to implement the program. Accordingly, Teshome (2001) strengthens this idea and suggested that teachers must understand the assessment process, feel secure about it, and accept it as their own for its effective implementation.

The result obtained from the interview of deans and vice deans shows that teachers have the basic skill of recording and documenting students' continuous assessment achievement. Most of them also accepted that teachers prefer continuous assessment than mid-exam and final exams. In addition to this, most of the respondents accepted and believed that continuous assessments are necessary to increase the academic achievement of students, solve students learning problems, and continuous assessment use 
uses a variety of assessment techniques. In line with this, Linn and Miller (2005: 26) state that continuous assessment is a general term that includes the full range of procedure used to gain information about students learning (observation, rating of performance, or projects, paper and pencil tests) and the formation of value judgment concerning learning progress.

\section{Practices of Continuous Assessment}

This study also came up with findings that are consistent with other previous research findings contrary to that of (Getinet, 2016; Berihu, 2016; Temesgen, 2017) that indicates that there was the low practice of continuous assessment in colleges of teachers education. In this study, the results concerning the current practice of continuous assessment suggest that it is possible to deduce the hardly possible way of continuous assessment practices in the College of teachers education e. Finding obtained from teachers and students shows that the teachers used a few types of continuous assessment tools such as assignments, quizzes, tests, mid and final exams are dominating the rest. Moreover, the findings revealed that most of the teachers used a similar continuous assessment. In spite of this, it was found out that assessment methods most frequently used were an assignment, quizzes tests and final examination. These findings agree with (Birhanu, 2016) who found out that teachers do not use various assessment methods to check the pupil's mastery of the desired knowledge, skills and attitudes, but rather focuses mostly on written tests and homework.

Results from the observation checklist also indicated the majority of teachers were not familiar to use oral questions, using a variety of continuous assessment tools, giving information about continuous assessment, encourage students to assess their own work and others' work. In addition to this, the interview and the document analysis result as well showed that teachers mostly used assignments, quizzes, tests, and exams. But, project and fieldwork were not used as tools of assessment. In line with this, Getinet (2016) observed that the actual practices of continuous assessment by teachers were; exams, tests, quiz, individual and group assignments were the most commonly used assessment methods at the end of each unit. This finding indicates that instruments for assessing the cognitive domain were highly used by the teachers and they are most often used for assessing students' knowledge of content.

The instruments for assessing the affective and psychomotor domains were less used. This was not satisfied with the definition of continuous assessment as stated by (Obioma, 2005). Regarding this, Quansha (2005: 2-3) found that the current continuous assessment system no attention is given to project work, which is the most important learning medium that allows pupils to take an active part in their own learning.

\section{The Major Factors that Influence the Practices of} continuous assessment

The study revealed that the major factors affecting the practices of continuous assessment are: class size, Shortage of time, the interest of the students, Teachers workload, large instructional content and lack of commitment among teachers.

Class size concerns with learning to occur positively when lessons are under appropriate conditions both for the teacher and students. Similarly, Hayes (1997) contended that the problem of large class size is very serious to assess student's classwork and homework. Teachers who teach many students in overcrowded classrooms often say that it is certainly not suitable to provide activities for such classes. In line with this, Tesfaye (2005) state that teachers commonly complain that the class-size is hampering their attempt at practicing continuous assessment and recording each and every student's performance. The study shows that there are poor classroom conditions which not suitable to practice continuous assessment in the classroom. The data gathered from the questionnaire and interview shows that the numbers of students in the class are large and so it is difficult to evaluate, manage, and practice continuous assessment as an intended whole.

Concerning challenges of continuous assessment, most of the respondents of teachers were also accepted class size, Shortage of time, Low interest of students, Teachers workload, Large instructional content and Lack of commitment among teachers were the major factors that influence the practice of continuous assessment in their learning activities. In addition to this, interviews of deans and vice deans results also showed that class size, Shortage of time, Low interest of students, Teachers workload, Large instructional content and Lack of commitment among teachers were the major factors that affecting the practice of continuous assessment in their colleges.

According to Abera (2012) observed that teachers fail to use continuous assessment in the classroom due to the following challenges. These are: a) large class size, b) lack of commitment and c) broad course content. Successful implementation of continuous assessment demands more work time and responsibility on the part of teachers. As could be observed from the data, the participants had the perception that time was one of the constraints which influenced them not to fully implement continuous assessment as effectively as possible. Among the factors that were identified hindering the implementation of continuous assessment is the lack of commitment by teachers. From the data gathered from the dean and vice dean complaining teachers are over-loaded with many courses. As a result, teachers are expected to complete the course from which they are assigned to offer according to the schedule. This makes teachers focus on chapter cover than the use of continuous assessment.

\section{CONCLUSIONS}

Based on the above findings of the study, the following conclusions were drawn:

1. Continuous assessment practice at Teacher Education Colleges in Western Oromia region of Ethiopia is ineffective and null practiced. 
2. The study also revealed that though college teachers exhibited positive perception, because of weekly workload unable to implement or practice continuous assessment.

3. The finding disclosed that large class size, shortage of time, teachers workload, the low interest of students, large instructional content, and lack of commitment among teachers as the major factors hindering the practice of continuous assessment in colleges of teachers education.

\section{REFERENCES}

Abera, A. (2012). Continuous Assessment (Ca) Vis- ̀̀-Vis the Attainment of Major Educational Domains of Physical Education in Ethiopia. International Journal of Social Science \& Interdisciplinary Research. 1(11), 14-27.

Airasian, P.W. (1994). Classroom Assessment. New York: McGraw-Hill, Inc.

Apple, M., \& Shimo, E. (2004). Learners to Teacher: Portfolio Please! Perceptions of Portfolio Assessment in EFL Classroom.

Argall, M. W. ( 2001). Ideology and the curriculum. New York: Rout! Ooge.

Berihu, A. (2016). Implementation of Continuous Assessment and Its Effectiveness in Adwa College of Teacher Education, Ethiopia. .International Journal of Education, Culture and Society. 1(1), 16-22.

Black, P., \& Wiliam, D. (1998). Inside the Black Box: Raising Standards through Classroom Assessment.

Brown, G., Bull, J., \& Pendlebury, M. (1997). Assessing Students Learning in Higher Education. London: Routledge.

Brown, S., \& Knight, P. (1994). Assessing Learners in Higher Education, London: Routledge Flamer.

Creswell, J. (2012). Educational research: Planning, conducting, and evaluating, conducting, and evaluating quatitative and qualitative research $\left(4^{\text {th }}\right.$ ed.). Bosten: Person Education, Inc.

Ellington, H., \& Earl, S. (1997). Making Effective Use of Continuous assessment and Portfolios. Available on: file://apu.gcal.ac.uk/ciced/ch 25.html-56k.

Ertmer, P., \& Newby, T. (1993). Behaviorist, Cognitivist, Constructivism: comparing critical features from an instructional design perspectives. Journal of performance improvement Quartery, 6(4), 5-72.

Gensee, F., \& Upshure, A. (1996). Classroom Based Evaluation in Second Language Education. Cambridge: Cambridge University Press.

Getinet, S. (2016). Assessment of the Implementation of Continuous Assessment: the case of METTU university. European Journal of Science and Mathematics Education. 4(4), 534-544, Beinjing 100081, China.

Greaney, V., \& Kellaghan, T. (2001). Using Assessment to Improve the Quality of Education. Paris: International Institute for Educational Planning.
Hayes, D. (1997). Helping Teachers to cope with Large Classes. ELT journal, 51(2).

Ipaye, T. (1982). Continuous Assessment in Schools (With Some Counseling Applications. Ilorin: Ilorin University Press.

Lewis, A. C. (1997). Changing assessment, changing curriculum. Education Digest.

Linn, R. L., \& Miller, M. D. (2005). Measurement and assessment in teaching, (9th ed.). Upper Saddle River, NJ: Merrill/PrenticeHall.

Madaus, \& Kellagan, (1993). Basic Concepts of Continuous Assessment. New York: Magraw- Hill.Inc.

Martin, J. (1997). Elementary Science Methods: A constructive Approach. USA: Delmar Publishers.

Mercy, K. (2012). Assessment Problems in Zimbabwe's Primary Schools with special reference to Gweru district schools. Doctoral Dissertation. Zimbabwe: Open University.

Miller P. H. (2005). Theories of developmental psychology ( $5^{\text {th }}$ ed. $)$.

MoE. (1994). Education and Training Policy. Addis Ababa: Educational Materials Production.

Nitko, J. A. (1996). Educational Assessments (2 nd ed). Englewood: Prentice-Hall, Inc.

NOE. (2004). Guidelines for Continuous Assessment. Ethiopia: Addis Ababa.

Obioma, G. (2005). Educational Assessment in the Culture of Reform Context. Paper Presented at the 31St Annual Conference of the International Association for Educational Assessment (IAEA), held at the Nicon Hilton Hotel, Abuja.

Papworth, H. (2005). A VSO CPD Advisors View of Continuous Assessment in Ethiopia. A paper Presented to the National Workshop on Continuous Assessment organized by AED/BESO, Addis Ababa.

Paris, S. G., \& Lawton, T. A. (1991). A developmental perspective on standardized achievement testing. Educational Researchers.

Puhl, C. A. (1997). Develop, Not Judge: Continuous Assessment in the ESL classroom. Forum Online, 35(2). Available at: http://exchages.state.gov/forum/vols/vol35/no2/p2. $\underline{\mathrm{htm}}$

Spandel \& Stiggins (1990). Assessment and Evaluation. Retrived from: Evaluation. http://www.sasked.gov.sk.ca/docs/mla/assess.html.

Struyven, K., Dochy, F. \& Janssens, S. (2002). Student's Perceptions about assessment in Higher Education. http:// www. leads.uk/ educol/document/00002255.html.

Takele, A. (2010). The state of continuous assessment practices in secondary schools of Oromia special Zone: Challenges and prospects. M.A. Thesis. Ethiopia: Addis Ababa.

Temesgen, S. (2017).Teachers' Perception and Practices to wards Continuous Assessment of Mathematics Classes: The Case of Secondary School in Wolaita Zone, Snnpr Region. Journal of Education and 
Practice, 8(22), Wolaita Sodo University, Wolaita Sodo, Ethiopia.

Tesfaye, S. (2005). Continuous Assessment in Teacher Education Programs: Sharing the Experience of Debub University. A paper presented on national workshop on continuous assessment. Addis Ababa.

Teshome, D. (2001). Assessment of pupils' achievement in the teaching English: Training and practice in focus. The Ethiopian Journal of Education, 21(1), 25-40.

Ugodulunwa, C. A. (1996). Crisis Continues Assessment Practices: Challenges for Measurement Expert.
Journal of Science and Education Forum, 1(1), 8692.

USAID/BEP. (2006b). A concise manual for developing and implementing continuous assessment in teacher education institutions and primary schools of Ethiopia: Addis Ababa. Academy for educational Development (AED) in consortium with Ministry of Education (MOE)

Yin, R. K. (2011). Qualitative Research from Start to Finish. New York, NY: The Guilford Press. 